\title{
Energy allocation in two species of Eutardigrada
}

\author{
Roberto GUIDETTI*, Chiara COLAVITA, Tiziana ALTIERO, Roberto BERTOLANI and Lorena REBECCHI \\ Department of Animal Biology, University of Modena and Reggio Emilia, Via Campi 213/D, Modena, Italy \\ *e-mail corresponding author: guidetti.roberto@unimore.it
}

\begin{abstract}
To improve our knowledge on life histories in tardigrades and the energy allocated for their reproduction and growth, we have studied two species (Macrobiotus richtersi and Hypsibius convergens) differing in evolutionary histories, diet and ways of oviposition. For both species we considered a bisexual population dwelling in the same substrate. In both species we investigated energy allocations in males with a testis rich in spermatozoa and females, each with an ovary containing oocytes in advanced vitellogenesis. The age of the specimens was estimated on the basis of buccal tube length and body size. Body and gonad areas were calculated using an image analysis program. In both species females reach a larger size than males. Macrobiotus richtersi has both a significantly longer buccal tube and wider body area than H. convergens. Statistical analyses show that the buccal tube has a positive correlation with body area and gonad area. For an estimate of the relative energy allocated for reproduction in one reproductive event (relative reproductive effort $=R R E$ ), we have used the ratio between gonad area and body area. In males of both species, the absolute amount of energy and the RRE is statistically lower than that of females. Males and females of $\mathrm{H}$. convergens have a RRE higher than those of $\mathrm{M}$. richtersi. In M. richtersi, the gonad increases proportionally more when animals are large (old), whereas in $\mathrm{H}$. convergens this direct relationship is not detectable. In M. richtersi the energy allocated for a reproductive event increases during the life of the females. In males, the increase of the gonad size is progressive during the animal life. In each reproductive event, females of $\mathrm{H}$. convergens allocate a lower amount of energy in absolute value when compared to M. richtersi. Nevertheless, when considering the RRE, their investment is higher than that of $\mathrm{M}$. richtersi.
\end{abstract}

Key words: Tardigrada, reproductive effort, trade-off, Macrobiotus richtersi, Hypsibius convergens, energy allocation

\section{INTRODUCTION}

Tardigrades allocate energy in growth (through an indeterminate number of molts), maintenance of somatic tissues, storage, and other activities. This implies physiological trade-offs, i.e., energetic allocation among processes that directly compete with one another for limited resources of the animal. Maintenance energy is usually assumed to have priority over other needs (Jokela \& Mutikainen 1995; Heino \& Kaitala 1999). Surplus energy is energy in excess of maintenance that can be allocated to other functions, such as locomotion, stress responses (e.g. cryptobiosis), and feeding, other than reproduction.

Even though tardigrades are not true euthelic animals (mitoses are present in somatic and germinal tissues; Bertolani 1970a), during their somatic growth they maintain a constant cell number in most tissues (Bertolani 1970b). Tardigrades consume energy increasing their body size mainly with a cell size increase and producing new cuticular structures (cuticle, claws, buccal tube, and placoids) during each molt. They do not recover old cuticular structures; therefore, the energy used to renew them is lost. In tardigrades, surplus energy is partially stored in storage cells floating in the body cavity (May 1946/1947; Rosati 1968; Węglarska 1975; Szymanska 1994). The consumption of this surplus energy has been evidenced during stress responses. A reduction of storage cell sizes has been observed in relationship to anhydrobiotic processes (Jönsson \& Rebecchi 2002) and in relationships to reproduction (Szymanska 1994). Another very high energetic cost bound to stress response is represented by the encystment (found in some tardigrades), in which several bucco-pharyngeal apparatuses and cuticles are serially produced (Guidetti et al. 2006).

Data on tardigrade life histories are still limited (Suzuki 2003; Altiero et al. 2006; Hohberg 2006) and energy allocations for reproduction and associated trade-offs have been little investigated.

In their study on phenotypic factors affecting anhydrobiotic survival, Jönsson \& Rebecchi (2002) found that animal reproductive stages did not affect survival, whereas body size and energetic condition, indicated by storage cell sizes, interact in affecting survival probability.

To improve our knowledge on energy allocation, we considered specimens of bisexual populations of Macrobiotus richtersi Murray, 1911 and Hypsibius convergens (Urbanowicz, 1925) living in the same substrate but differing in evolutionary histories (belonging to Macrobiotidae and Hypsibiidae, respectively), diet, and way of oviposition. All eutardigrade females mature and lay groups of eggs throughout adult life in association with molt (Rebecchi \& Bertolani 1994). According to Bell's (1976) definition, tardigrade females are semicontinuous iteroparous. The reproductive patterns of eutardigrade males vary among species, for example in 
$M$. richtersi there is a continuous maturation in a zonal gonad, i.e., the mature testis always contains groups of germ cells at different maturation stages, including spermatozoa (Rebecchi \& Bertolani 1994). The reproductive pattern of $H$. convergens is unknown.

\section{METHODS}

Samples of two layers of beech litter (from 0 to $3 \mathrm{~cm}$ and from 3 to $6 \mathrm{~cm}$ in depth) were collected bimonthly from July 1997 to July 1998 (7 samplings) in a woody area at Piane di Mocogno (Northern Apennines, Modena, Italy), $1200 \mathrm{~m}$ a.s.l. Tardigrades were extracted from beech litter using modified Baermannfunnels. Animals were then fixed in Carnoy fluid (methanol: acetic acid 3:1; v/v), stained with acetic carmine and finally mounted on slides with a standard amount (two drops) of Faure-Berlese mounting medium.

The reproductive investment of tardigrades was estimated on the basis of gonad size because the absolute amount of energy devoted to reproduction could not be determined in these small animals. Gonad size reflects the gonad productivity and gives an estimate of the reproductive resource budget (Schärer et al. 2005). The somatic investment has also been inferred on animal sizes. If we consider reproductive effort as the amount of energy allocated to reproductive tissues in a defined time (e.g. the time of a reproductive event), an estimation in relative terms of such an amount (here called relative reproductive effort: RRE) can be obtained by the ratio between gonad area and body area.

All measurements were carried out only on well positioned and extended tardigrades (Fig. 1) with mature germinal cells (i.e. testis with spermatozoa, ovary with oocytes in advanced vitellogenesis). Animal and buccal tube lengths were measured according to Pilato (1981). For the evaluation of body and gonad areas, digital images $(400 \times 300$ pixels $)$ were acquired using a Polaroid DMC 1e LowLight Kit photo-camera connected to a Leitz DM RB microscope. An objective with $20 \times$ magnification was used for body area, $40 \times$ for ovary area, and $100 \times$ for testis area. Body areas were determined excluding legs. Gonad areas did not include gonoducts. Area measurements were obtained by the image analysis program Image Pro Plus, available at Centro Interdipartimentale Grandi Strumenti of the University of Modena and Reggio Emilia. Percentage errors of area measurement were calculated as sd $100 \mathrm{~m}^{-1}(\mathrm{sd}=$ standard deviation of 10 measurements of the same area; $\mathrm{m}=$ mean area of the 10 measurements). Inferential test of allometry and related $\mathrm{Z}$ statistics were performed according to Skelton (1993). When $Z$ was considerably different than \pm 1.96 the relationship between measures was considered allometric; if not, it was considered isometric.
Statistical analyses (ANOVA, Regression analysis, Pearson Correlation test) were performed with SPSS and Excel.

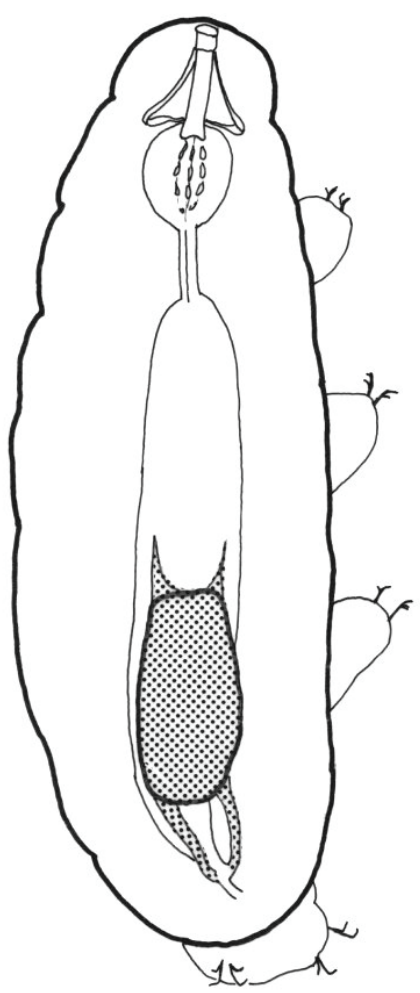

Fig. 1. Scheme of a well positioned animal (male) to measure body and gonad (mature testis) areas. Bold lines represent the measured areas. Dotted area $=$ gonad.

\section{RESULTS}

\subsection{Macrobiotus richtersi}

Animals were found in both layers considered and in lower numbers in November and January. The population was bisexual. Of a total of 572 specimens, 118 were recognizable as males with sperms, but only 14 were females with oocytes in advanced vitellogenesis (out of a total of 63 females identified). In several specimens we were not able to identify sex. Males were present in all samplings and represented a large fraction of the population (Fig. 2), whereas females with mature oocytes represented a low fraction of the population.

Males have shorter buccal tube length, are shorter, have smaller body size (mean 2.6 times) and gonad areas (mean 13.6 times) than females (Tabs 1 and 2). Body areas of the largest females are 4.8 times than those of the smallest mature ones; those of the largest males are 8.3 times than those of smallest mature males (Tab. 1). 




Macrobiotus richtersi

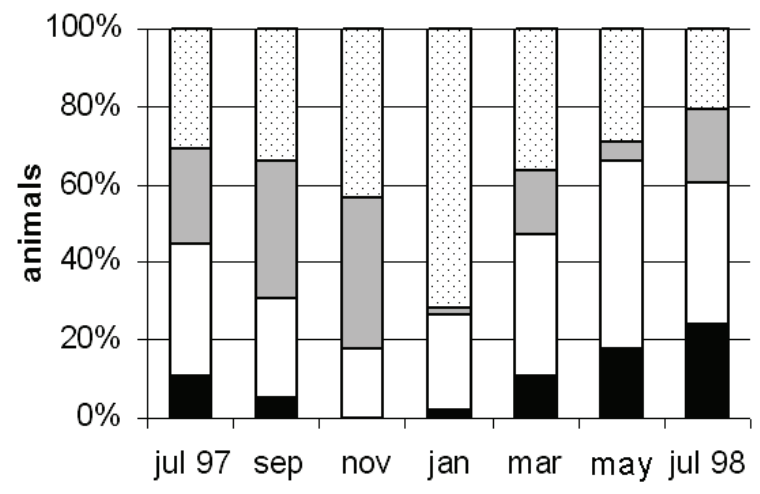

females $\square$ males $\square$ undifferentiated $\square$ indeterminate

Fig. 2. Percentage of males, females, undifferentiated and indeterminate animals within populations of Macrobiotus richtersi and Hypsibius convergens.

Tab. 1. Buccal tube length $(\mu \mathrm{m})$, body length $(\mu \mathrm{m})$, body area $\left(\mu \mathrm{m}^{2}\right)$, gonad area $\left(\mu \mathrm{m}^{2}\right)$ and RRE in Macrobiotus richtersi.

n. $=$ number of specimens; max mean $=$ mean of the four largest measurements; min mean $=$ mean of the four smallest measurements; max $\min ^{-1}=$ ratio of the mean of the four largest measurements and mean of the four smallest. Percentage error of measurements: $1.5 \%$ for body areas, $0.9 \%$ for female gonad areas, $0.5 \%$ for male gonad areas.

\begin{tabular}{|c|c|c|c|c|c|c|c|c|}
\hline & $\mathrm{n}$. & mean & (SD) & max mean & (SD) & min mean & (SD) & $\max \min ^{-1}$ \\
\hline males + females & 132 & & & & & & & \\
\hline tube length & & 38.7 & (6.1) & 54.5 & (3.8) & 26.0 & $(2.8)$ & 2.1 \\
\hline body length & & 344.9 & $(86.5)$ & 610.0 & $(82.5)$ & 210.0 & (11.5) & 2.9 \\
\hline body area & & 38446 & $(27657)$ & 146764 & $(30451)$ & 11734 & $(208)$ & 12.5 \\
\hline gonad area & & 6414 & (15004) & 79182 & $(27795)$ & 422 & (97) & 187.6 \\
\hline RRE & & 0.11 & $(0.11)$ & 0.56 & $(0.06)$ & 0.03 & (0) & 18.7 \\
\hline males & 118 & & & & & & & \\
\hline tube length & & 37.6 & $(5.1)$ & 48.0 & $(1.3)$ & 26.0 & $(2.8)$ & 1.8 \\
\hline body length & & 335.9 & $(70.6)$ & 490.0 & (14.1) & 210.0 & (11.5) & 2.3 \\
\hline body area & & 32835 & $(16720)$ & 97644 & (8492) & 11734 & (208) & 8.3 \\
\hline gonad area & & 2725 & $(1758)$ & 8928 & (1864) & 422 & (97) & 21.2 \\
\hline RRE & & 0.08 & $(0.06)$ & 0.39 & $(0.02)$ & 0.01 & $(0.01)$ & 39.0 \\
\hline females & 14 & & & & & & & \\
\hline tube length & & 48.9 & $(5.6)$ & 54.5 & $(3.8)$ & 43.6 & $(2.9)$ & 1.3 \\
\hline body length & & 447.1 & $(135.3)$ & 610.0 & $(82.5)$ & 290.0 & $(25.8)$ & 2.1 \\
\hline body area & & 84938 & $(50085)$ & 146764 & $(30450)$ & 30573 & (11846) & 4.8 \\
\hline gonad area & & 36982 & (32847) & 79182 & (27795) & 5070 & (1559) & 15.6 \\
\hline RRE & & 0.37 & $(0.16)$ & 0.56 & $(0.06)$ & 0.18 & $(0.06)$ & 3.1 \\
\hline
\end{tabular}


Tab. 2. Values of $\mathrm{P}$ between parameters in Macrobiotus richtersi (Pearson Correlation test).

$\mathrm{bt}=$ buccal tube; $\mathrm{bl}=$ body length; $\mathrm{ba}=$ body area; $\mathrm{ga}=\operatorname{gonad}$ area $\mathrm{RRE}=$ relative reproductive effort; $\mathrm{M}=$ males; $\mathrm{F}=$ females; $\mathrm{M}+\mathrm{F}=$ males + females; $\mathrm{F} \mathrm{M}^{-1}=$ ratio of the male mean values and of female mean values.

\begin{tabular}{|c|c|c|c|c|c|c|c|c|c|c|c|c|c|c|c|c|c|}
\hline & \multicolumn{3}{|c|}{ bt } & \multicolumn{3}{|c|}{ bl } & \multicolumn{3}{|c|}{ ba } & \multicolumn{3}{|c|}{ ga } & \multicolumn{3}{|c|}{ RRE } & \multirow[t]{2}{*}{$\mathrm{F} v s \mathrm{M}$} & \multirow[t]{2}{*}{$\mathrm{F} \mathrm{M}^{-1}$} \\
\hline & $\mathrm{M}+\mathrm{F}$ & $\bar{F}$ & $\mathrm{M}$ & $\mathrm{M}+\mathrm{F}$ & F & $\mathrm{M}$ & $\mathrm{M}+\mathrm{F}$ & F & $\mathrm{M}$ & $\mathrm{M}+\mathrm{F}$ & $\mathrm{F}$ & $\mathrm{M}$ & $\mathrm{M}+\mathrm{F}$ & F & $\mathrm{M}$ & & \\
\hline bt & & & & $<0.001$ & 0.042 & $<0.001$ & $<0.001$ & $<0.001$ & $<0.00$ & $<0.001$ & $<0.001$ & $<0.0$ & $<0.001$ & 0.000 & 0.000 & $<0$. & 1.3 \\
\hline bl & $<0.001$ & 0.042 & $<0.001$ & & & & $<0.001$ & 0.003 & 0.000 & $<0.001$ & 0.020 & $<0.001$ & $<0.001$ & & 0.029 & $<0.001$ & 1.3 \\
\hline ba & $<0.001$ & $<0.001$ & $<0.001$ & $<0.001$ & 0.003 & $<0.001$ & & & & $<0.001$ & $<0.001$ & $<0.001$ & $<0.001$ & 0.002 & 0.002 & $<0.001$ & 2.6 \\
\hline ga & $<0.001$ & $<0.001$ & $<0.001$ & $<0.001$ & 0.020 & $<0.001$ & $<0.001$ & $<0.001$ & $<0.001$ & & & & $<0.001$ & 0.000 & 0.000 & $<0.001$ & 13.6 \\
\hline RRE & $<0.001$ & $<0.001$ & $<0.001$ & $<0.001$ & & 0.029 & $<0.001$ & 0.002 & 0.002 & $<0.001$ & $<0.001$ & $<0.001$ & & & & $<0.001$ & 4.1 \\
\hline
\end{tabular}

Macrobiotus richtersi

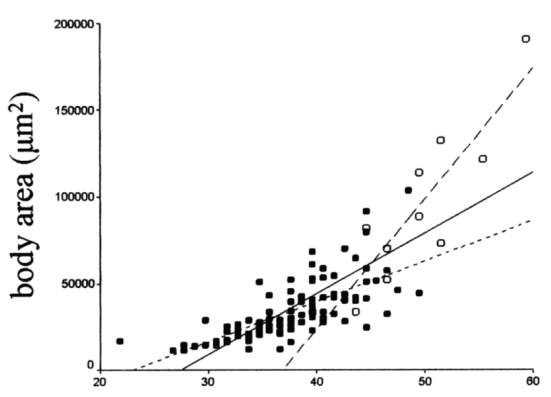

buccal tube length $(\mu \mathrm{m})$

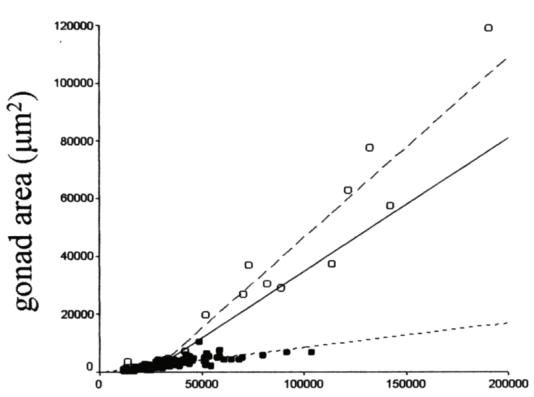

body area $\left(\mu \mathrm{m}^{2}\right)$

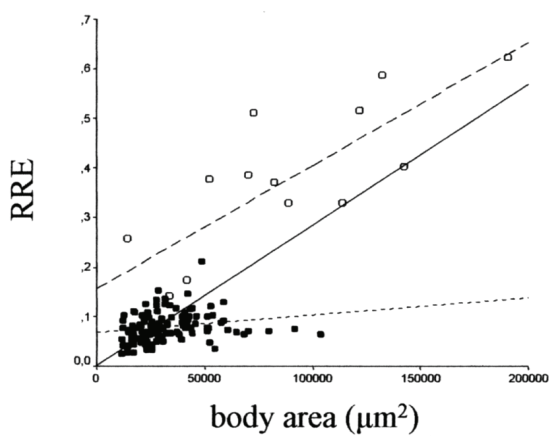

Hypsibius convergens
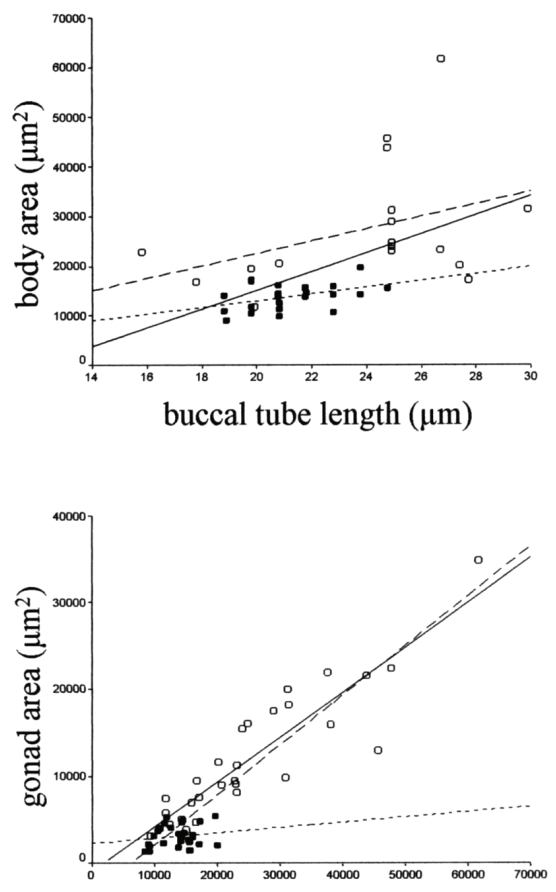

body area $\left(\mu \mathrm{m}^{2}\right)$

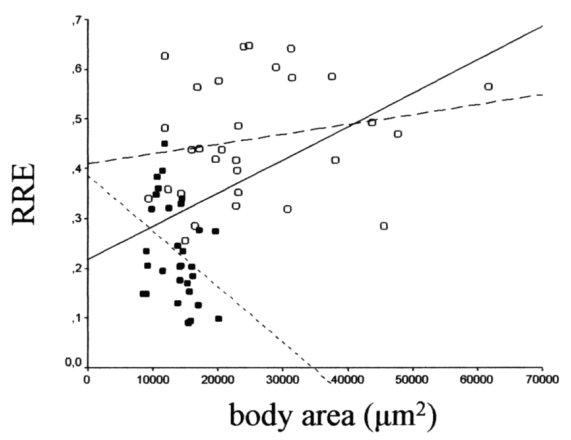

Fig. 3. Relationships of body area with buccal tube length, gonad area, and RRE in Macrobiotus richtersi and Hypsibius convergens. $\square=$ females; $\mathbf{~}=$ males. Linear regressions: ........ = females, $------=$ males, $-=$ males + females.

Considering both sexes, either together or separately, buccal tube length is directly related to animal length, and to body and gonad areas (Fig. 3 and Tab. 2).

In both sexes, animal length is directly related to the body and gonad areas (Tab. 2) and the gonad areas are directly related to the body areas (Fig. 3 and Tab. 2). The buccal tube and the animal lengths result in an iso- metric relationship $(\mathrm{Z}$ of males plus females $=1.53 ; \mathrm{Z}$ of male $=1.50 ; Z$ of female $=1.59)$, whereas body and gonad areas result in allometric relationship ( $Z$ of males plus females $=9.46 ; \mathrm{Z}$ of male $=4.43 ; \mathrm{Z}$ of female $=$ 4.32).

Male RRE is lower than female RRE (Tab. 2), meanly 4.1 times smaller (Tabs 1 and 2). When analyz- 
Tab. 3. Buccal tube length $(\mu \mathrm{m})$, body length $(\mu \mathrm{m})$, body area $\left(\mu \mathrm{m}^{2}\right)$, gonad area $\left(\mu \mathrm{m}^{2}\right)$ and RRE in Hypsibius convergens.

$\mathrm{n} .=$ number of specimens; $\max$ mean $=$ mean of the four largest measurements; min mean $=$ mean of the four smallest measurements; max $\min ^{-1}=$ ratio of the mean of the four largest measurements and mean of the four smallest. Percentage error of measurements: $1.5 \%$ for body areas, $0.9 \%$ for female gonad areas, $0.5 \%$ for male gonad areas.

\begin{tabular}{|c|c|c|c|c|c|c|c|c|}
\hline & $\mathrm{n}$. & mean & (SD) & max mean & (SD) & min mean & (SD) & $\max \min ^{-1}$ \\
\hline males + females & 59 & & & & & & & \\
\hline tube length & & 22.5 & $(3.0)$ & 28.2 & $(1.3)$ & 18.3 & $(1.0)$ & 1.5 \\
\hline body length & & 275.2 & $(55.5)$ & 390.0 & (11.5) & 195.0 & $(10.0)$ & 2.0 \\
\hline body area & & 19469 & (10748) & 49694 & (8152) & 8932 & (293) & 5.6 \\
\hline gonad area & & 7524 & (6794) & 25186 & (6432) & 1377 & (94) & 18.3 \\
\hline RRE & & 0.35 & $(0.08)$ & 0.34 & $(0.01)$ & 0.10 & $(0.02)$ & 3.4 \\
\hline males & 29 & & & & & & & \\
\hline tube length & & 21.2 & (1.7) & 23.8 & $(0.8)$ & 19.1 & $(0.5)$ & 1.2 \\
\hline body length & & 252.0 & $(29.5)$ & 295.0 & $(10.0)$ & 205.0 & $(10.0)$ & 1.4 \\
\hline body area & & 13557 & (3080) & 18494 & (1602) & 8932 & (293) & 2.1 \\
\hline gonad area & & 3080 & (1118) & 4766 & (104) & 1377 & (94) & 3.5 \\
\hline RRE & & 0.23 & $(0.10)$ & 0.40 & $(0.04)$ & 0.10 & $(0.02)$ & 4.0 \\
\hline females & 30 & & & & & & & \\
\hline tube length & & 24.1 & (3.7) & 28.2 & $(1.3)$ & 18.8 & $(1.4)$ & 1.5 \\
\hline body length & & 298.3 & (65.5) & $\begin{array}{l}20.2 \\
390.0\end{array}$ & (11.5) & 200.0 & (16.3) & 2.0 \\
\hline body area & & 25381 & (12378) & 49694 & (8151) & 11295 & (1390) & 4.4 \\
\hline gonad area & & 11969 & (7178) & 25186 & (6432) & 4027 & (693) & 6.3 \\
\hline RRE & & 0.46 & $(0.12)$ & 0.64 & $(0.01)$ & 0.28 & $(0.02)$ & 2.3 \\
\hline
\end{tabular}

Tab. 4. Values of $\mathrm{P}$ between parameters in Hypsibius convergens (Pearson Correlation test).

$\mathrm{bt}=$ buccal tube; $\mathrm{bl}=$ body length; $\mathrm{ba}=$ body area; $\mathrm{ga}=$ gonad area; $\mathrm{RRE}=$ relative reproductive effort; $\mathrm{M}=$ males; $\mathrm{F}=$ females; $\mathrm{M}+\mathrm{F}=$ males + females; $\mathrm{F} \mathrm{M}^{-1}=$ ratio of the male mean values and of female mean values.

\begin{tabular}{|c|c|c|c|c|c|c|c|c|c|c|c|c|c|c|c|c|c|}
\hline & \multicolumn{3}{|c|}{ bt } & \multicolumn{3}{|c|}{ bl } & \multicolumn{3}{|c|}{$\mathrm{ba}$} & \multicolumn{3}{|c|}{ ga } & \multicolumn{3}{|c|}{ RRE } & \multirow[t]{2}{*}{$\mathrm{F} v s \mathrm{M}$} & \multirow[t]{2}{*}{$\mathrm{F} \mathrm{M}^{-1}$} \\
\hline & $\mathrm{M}+\mathrm{F}$ & F & $\mathrm{M}$ & $\mathrm{M}+\mathrm{F}$ & F & $\mathrm{M}$ & $\mathrm{M}+\mathrm{F}$ & F & $\mathrm{M}$ & $\mathrm{M}+\mathrm{F}$ & $\mathrm{F}$ & $\mathrm{M}$ & $\mathrm{M}+\mathrm{F}$ & $\mathrm{F}$ & $M$ & & \\
\hline bt & & & & $<0.001$ & 0.010 & & $<0.001$ & & 0.040 & $<0.001$ & 0.028 & & 0.008 & & & 0.003 & 1.1 \\
\hline bl & $<0.001$ & 0.010 & & & & & $<0.001$ & 0.001 & $<0.001$ & $<0.001$ & 0.003 & & 0.006 & & & 0.003 & 1.2 \\
\hline ba & $<0.001$ & & 0.040 & $<0.001$ & 0.001 & $<0.001$ & & & & $<0.001$ & $<0.001$ & & $<0.001$ & & & $<0.001$ & 1.9 \\
\hline ga & $<0.001$ & 0.028 & & $<0.001$ & 0.003 & $<0.001$ & $<0.001$ & $<0.001$ & & & & & $<0.001$ & 0.000 & 0.000 & $<0.001$ & 3.9 \\
\hline RRE & 0.008 & & & 0.006 & & & $<0.001$ & & & $<0.001$ & $<0.001$ & $<0.001$ & & & & $<0.001$ & 2.0 \\
\hline
\end{tabular}

ing males plus females, RRE is directly related to buccal tube and animal lengths, and to body areas (Fig. 3 and Tab. 2). Considering genders separately, these relationships are still present, with the exception of the relationship between RRE and animal length in females (Tab. 2).

The mean number of oocytes within the ovary is 3.5 $(\mathrm{SD}=2.1$; highest value $=6$, lowest $=1)$.

\subsection{Hypsibius convergens}

Animals were found mainly in the upper leaf litter layer. They were in lower number from July to November. A few cysts have been found. The population is bisexual. We collected 692 animals. Of them we identified 30 males with sperms and 124 females (30 of them with oocytes in advanced vitellogenesis).

Males of $H$. convergens are characterized by a continuous and simultaneous presence of different maturative stages of germinal elements, spermatozoa included. The maturation is zonal, as in $M$. richtersi. Females mature and lay groups of smooth eggs inside the exuvium. Males, when present, represent a low fraction of population (Fig. 2); females with mature oocytes were present in all samplings.
Males are shorter with shorter buccal tube lengths and a smaller body size (mean 1.9 times) and gonad areas (mean 3.9 times) than females (Tabs 3 and 4). The body areas of the largest females are about 4.4 times those of the smallest mature females, whereas this ratio is 2.1 in males (Tab. 3).

Considering sexes together, the buccal tube length is directly related to body length and to body and gonad areas (Fig. 3 and Tab. 4). Animal and buccal tube lengths have an allometric relationship $(Z=-2.07)$, as do body and gonad areas $(Z=4.26)$. In females, animal length is directly related to buccal tube length and to body and gonad areas; the gonad area is directly related to buccal tube length, to animal length, and to body area (Fig. 3 and Tab. 4). Animal and buccal tube lengths have an isometric relationship $(Z=-1.59)$, as do body and gonad areas $(Z=1.44)$. In males, animal length is directly related to body area, whereas gonad area is not related with any other morphometric character (Fig. 3 and Tab. 4). Male RRE is lower than female RRE (Tabs 3 and 4). Males plus females RRE is directly related to buccal tube and animal lengths and to body areas (Tab. 4). These relationships cannot be confirmed when sexes are analyzed separately (Tab. 4). 
The mean number of oocytes within the ovary is 5.1 $(\mathrm{SD}=2.4$; highest value $=9$, lowest $=2)$.

\subsection{Macrobiotus richtersi vs Hypsibius convergens}

The percentages of mature males are always higher in $M$. richtersi than in $H$. convergens, whereas percentages of females are generally higher in $H$. convergens as compared to $M$. richtersi (Fig. 2).

The specimens of $M$. richtersi have a longer body and buccal tube and larger body area than those of $H$. convergens (Tab. 5). In absolute value $M$. richtersi females have a larger gonad than $H$. convergens females (Tab. 5), whereas $H$. convergens males have a marginally significant larger gonad than $M$. richtersi males (Tab. 5). The RRE of H. convergens females and males are higher than those of $M$. richtersi (Tab. 5).

Tab. 5. Macrobiotus richtersi vs Hypsibius convergens. The $\mathrm{P}$ values of statistical analyses are reported. (ANOVA).

\begin{tabular}{lccc}
\hline & males & females & males+females \\
\hline buccal tube length & $<0.001$ & $<0.001$ & $<0.001$ \\
body length & $<0.001$ & $<0.001$ & $<0.001$ \\
body area & $<0.001$ & $<0.001$ & $<0.001$ \\
gonad area & 0.055 & 0.003 & $<0.001$ \\
RRE & $<0.001$ & 0.034 & $<0.001$ \\
\hline
\end{tabular}

\section{DISCUSSION}

The two species considered live in the same substrate but are characterized by different reproductive strategies and probably different life cycles, even though both can be considered $r$-strategists. Difference in the reproductive strategy is reflected in the way of oviposition in eutardigrades. Even though in eutardigrades oviposition is always associated with molt (Bertolani 2001), M. richtersi, as do all macrobiotids, lays free ornamented eggs. In contrast, $H$. convergens, as many hypsibiids, lays smooth eggs within the exuvium. In $M$. richtersi, the eggs of the same clutch are not always laid in one event (Hohberg 2006; Altiero pers. comm.) and can hatch at different times (Altiero et al. 2006; Hohberg 2006). These strategies can scatter the eggs widely in space and time. On the contrary, in $H$. convergens eggs are laid at one time reducing the scattering in space (no data are available on the hatching time).

The two species differ in the energy allocated to somatic growth and to reproduction. In tardigrades, buccal tube length and animal length are directly related (Higgins 1959; Rebecchi et al. 2006). Buccal tube length, animal length, and body area normally increase with age; therefore these characteristics can be used to determine the relative age of animals. On the other hand, we should consider that a smaller body size in males than in females characterizes both $M$. richtersi and $H$. convergens. A similar sexual dimorphism has previously been observed both in Arthrotardigrada and in Eutardigrada (see Bertolani 1992). No data exist in the literature on different sizes of newborns, either bound to their sex or to other factors (e.g. egg size, evolutionary histories). We can suppose that females and males of both species have similar sizes at hatching and that in both species and in both sexes the different sizes of mature animals should represent the increase of body sizes during the lifespan. As the area increases proportionally less than the volume, we should consider differences in body volumes higher than those in body areas. Volume is proportional to biomass, i.e. to the amount of tissues needing supply with oxygen and nutrients. Our data show that tardigrades invest significant amounts of energy to tissues, and in particular, that $M$. richtersi invests a higher amount than $H$. convergens.

Males of $H$. convergens have continuous gonad maturation and are iteroparous, like those of $M$. richtersi (see Rebecchi \& Bertolani 1994). Females of H. convergens are confirmed to be iteroparous (Baumann 1961), or more specifically, semicontinuous iteroparous as in M. richtersi (see Rebecchi \& Bertolani 1994) and for all other eutardigrades, including the heterotardigrade echiniscids (Bertolani 2001). Males of both species mature at a smaller size than females, but in absolute and relative values they seem to invest less energy in reproduction than females. Female RRE values are double that of male RRE in $H$. convergens and quadruple of that in $M$. richtersi. The percentage of mature males is lower in $H$. convergens. Even though mature males are in lower numbers, they have a testis, that in absolute and relative values, is larger than that of $M$. richtersi males. These data represent further evidence that the two species have different reproductive strategies.

Size and age are important in any consideration of the reproductive effort. In both sexes of $M$. richtersi, gonad size increases with animal size and also with animal age. This is in accordance with life history theories stating that, in stable populations, the optimal reproductive investment should increase with age (Gadgil \& Bossert 1970; Charlesworth 1980). In animals with indeterminate growth, as female and most male tardigrades, fecundity of organisms of the same age usually increases with size (Stearns 1992), but current fecundity is related to previous reproductive decisions (Heino \& Kaitala 1999). In M. richtersi, the allometric relationship between body and gonad areas (together with the direct relationship between body area and RRE) evidence that the gonad increases proportionally more when animals are large (old). In M. richtersi, energetic investment devoted to oocytes production in a single reproductive event is higher in absolute and relative values in large animals than in small animals. In males with continuous germ cell maturation, the increase of gonad size is progressive during animal life.

Considering sexes together, $H$. convergens shows the same relationships between body and gonad areas found in $M$. richtersi. However, these relationships are 
not confirmed when sexes are analyzed separately. Females increase their gonad size in relationship to the increase of the animal size but in an isometric way, without relationships between animal size and RRE. These data imply that with age increase, gonads increase in size in absolute values but not in relative terms. Males of $H$. convergens, in contrast to females, show relationships neither between animal and gonad sizes nor RRE. The testis and its relative reproductive investment do not seem to increase in absolute and relative values with the size/age of animals. Nevertheless, females and males of $H$. convergens have RREs higher than those of males and females of $M$. richtersi.

Food supply can be considered among the proximate factors determining the reproductive investment (Thompson 1979; Stearns 1992). These statements seem valid for tardigrades, also: in Milnesium tardigradum Doyère, 1840 egg number per clutch decreases when food is reduced (Suzuki 2003). Food supply and other environmental factors affecting the resource allocation are generally age-, stage-, or size-dependent (Heino \& Kaitala 1999). Based on these assumptions, different RRE recorded between small and large animals can be related to the different food supply of animals in relationship to their size/age. Differences between the two species could be related to their different diets. Hypsibius convergens feeds on bacteria, fungi, and vegetal cells (Baumann 1961); M. richtersi is a carnivorous species feeding on nematodes, rotifers and other tardigrades (Altiero \& Rebecchi 2001; Guidetti \& Bertolani 2001; Hohberg \& Traunspurger 2005). All carnivorous tardigrades are relatively large animals, particularly the species belonging to the genus Milnesium, but also some Macrobiotus species, including M. richtersi. On the other hand, there are several herbivorous species characterized by large body sizes, e.g. many Dactylobiotus, Pseudobiotus, and some Macrobiotus. In $M$. richtersi, increase in body size allows an increase in predation rate (Hohberg \& Traunspurger 2005), and consequently, an increase in energy supplies.

Other differences between the two species are related to their population dynamics. In a two year study of the same populations, Guidetti (in preparation) found that the two species have seasonal variations with opposite trends. Macrobiotus richtersi is abundant during summer to early autumn periods, even though the number of animals is quite high during all seasons. Hypsibius convergens is abundant during winter to early spring periods with a reduced number of animals during other periods. We should stated that in summer there is a strong population decrease because cysts have been found always in a very limited numbers and specimens have been found mainly in the upper layer of leaf litter. This species is forced to concentrate its reproductive efforts within a relatively short time (few months) and to act as a fast colonizer. It establish a large community when conditions are favourable. Therefore, its RRE should always be high in such periods. The animals should mature in a short time, investing more energy to reproduction than to somatic growth $(H$. convergens specimens are smaller than $M$. richtersi specimens). Energy allocated to reproduction would always be high ( $H$. convergens has a RRE higher than $M$. richtersi). This strategy seems to fit the theoretical model developed by Heino \& Kaitala (1996) in which high levels of mortality select for early maturity, high reproductive effort, and smaller terminal size.

It has been proven that under laboratory conditions $M$. richtersi has a very long active lifespan (more than one year; Altiero et al. 2006). The long lifespan of $M$. richtersi allows a high investment of energy for somatic growth and consequently high amount of energy for reproduction ( $\mathrm{RRE}$ is higher when the animals are larger). Therefore, the increase of size gives a double selective advantage: increased predation rate and increased reproductive effort (in absolute and relative terms).

In tardigrades, reproduction is coupled to molt. Gonad size is constrained by the cuticle capacity and by the gut size (food sources) which competes for the space within the body cavity. The evolution of life-history traits are strictly connected with the energy allocation of organisms. The different characteristics found in the two species of tardigrades, $H$. convergens and $M$. richtersi, are defined by selective forces that solve contrasting actions of somatic and gonad growth on fitness.

\section{ACKNOWLEDGMENTS}

We would like to thank Juliana Hinton of the McNeese State University for the English revision and the two referees for their suggestions. Financial support for the research came from a grant FAR ex $60 \%$ and from a grant for the project MoMa - ASSC - TARSE supported by ASI.

\section{REFERENCES}

Altiero, T. \& L. Rebecchi. 2001. Rearing tardigrades: results and problems. Zool. Anz., 240: 217-212.

Altiero, T., L. Rebecchi \& R. Bertolani. 2006. Phenotypic variations in the life history of two clones of Macrobiotus richtersi (Eutardigrada, Macrobiotidae). Hydrobiologia, 588: 33-40.

Baumann, H. 1961. Der Lebensablauf von Hypsibius (H.) convergens Urbanowicz (Tardigrada). Zool. Anz., 167: 363-381.

Bell, G. 1976. On breeding more than once. Am. Nat., 110: 5777.

Bertolani, R. 1970a. Mitosi somatiche e costanza cellulare numerica nei Tardigradi. Atti Accad. Naz. Lincei, Rend., Ser. 8a, 48: 739-743.

Bertolani, R. 1970b. Variabilità numerica cellulare in alcuni tessuti di tardigradi. Atti Accad. Naz. Lincei, Rend., Ser. $8^{\mathrm{a}}, 49: 442-445$

Bertolani, R. 1992. Tardigrada. In: K.G. Adiyodi, R.G. Adiyodi (Eds), Reproductive Biology of Invertebrates. Sexual Differentiation and Behaviour. Vol. 5, Part B, Oxford and IBH Publishing Co., Pvt., Ltd., New Delhi: 255-266.

Bertolani, R. 2001. Evolution of the reproductive mechanisms in tardigrades - A review. Zool. Anz., 240: 247-252. 
Charlesworth, B. 1980. Evolution in age-structured populations. Cambridge University Press, New York: 300 pp.

Gadgil, M. \& W.H. Bossert. 1970. Life historical consequences of natural selection. Am. Nat., 104: 1-24.

Guidetti, R. \& R. Bertolani. 2001. The tardigrades of Emilia (Italy). III. Piane di Mocogno (Northern Apennines). Zool. Anz., 240: 377-383.

Guidetti R., D. Boschini, L. Rebecchi \& R. Bertolani. 2006. Encystment processes and "Matrioshka-like stage" cyst in a moss-dwelling and in a limnic species of eutardigrades (Tardigrada). Hydrobiologia, 558: 9-21.

Heino, M. \& V. Kaitala. 1996. Optimal resource allocation between growth and reproduction in clams: why does indeterminate growth exist? Funct. Ecol., 10: 245-251.

Heino, M. \& V. Kaitala. 1999. Evolution of resource allocation between growth and reproduction in animals with indeterminate growth. J. Evol. Biol., 12: 423-429.

Higgins, R.P. 1959. Life history of Macrobiotus islandicus Richters with notes on other tardigrades from Colorado. Trans. Am. Microsc. Soc., 78:137-154.

Hohberg, K. 2006. Tardigrade species composition in young soils and some aspects on life history of Macrobiotus richtersi J. Murray, 1911. Pedobiologia, 50: 267-274.

Hohberg, K. \& W. Traunspurger. 2005. Predator-prey interaction in soil food web: functional response, size-dependent foraging efficiency, and the influence of soil texture. Biol. Fertil. Soils, 41: 419-427.

Jokela, J. \& P. Mutikainen. 1995. Phenotypic plasticity and priority rules for energy allocation in a freshwater clam: a field experiment. Oecologia, 104: 122-132.

Jönsson, K.I. \& L. Rebecchi. 2002. Experimentally induced anhydrobiosis in the tardigrade Richtersius coronifer: phenotypic factors affecting survival. J. Exp. Zool., 293: 578-584.

May, M. 1946/1947. Cytologie des globules cavitaires actifs et dormants chez le tardigrade Macrobiotus hufelandi
Schultze. Arch. Anat. Microsc. Morphol. Exp., 36: 136150.

Pilato, G. 1981. Analisi di nuovi caratteri nello studio degli Eutardigradi. Animalia, 8: 51-57.

Rebecchi, L \& R. Bertolani. 1994. Maturative pattern of ovary and testis in eutardigrades of freshwater and terrestrial habitats. Invertebr. Reprod. Dev., 26: 107-117.

Rebecchi, L., R. Guidetti, S. Borsari, T. Altiero \& R. Bertolani. 2006. Dynamics of long-term anhydrobiotic survival of lichen-dwelling tardigrades. Hydrobiologia, 558: 23-30.

Rosati, F. 1968. Ricerche di microscopia elettronica sui Tardigradi. II. I globuli cavitari. Atti Accad. Fisiocrat. Siena, 17: 1439-1452.

Schärer, L., P. Sandner \& N.K. Michiels. 2005. Trade-off between male and female allocation in the simultaneously hermaphroditic flatworm Macrostomum sp. J. Evol. Biol., 18: 396-404.

Skelton, P. 1993. Evolution. A biological and palaeontological approach. The Bath Press, Avon, Great Britain: $1064 \mathrm{pp}$.

Stearns, S.C. 1992. The evolution of life histories. Oxford University Press, New York: 249 pp.

Suzuki, A.C. 2003. Life history of Milnesium tardigradum Doyère (Tardigrada) under a rearing environment. Zool. Sci., 20: 49-57.

Szymanska, B. 1994. Interdependence between storage bodies and egg developmental stages in Macrobiotus richtersi Murray, 1911 (Tardigrada). Acta Biol. Cracov., 36: 41-48.

Thompson, R.J. 1979. Fecundity and reproductive effort in the blue mussel (Mytilus edulis), the sea urchin (Strongylocentrotus droebachiensis), and the snow crab (Chionoecetes opilio) from populations in Nova Scotia and Newfoundland. J. Fish. Res. Board Can., 36: 955-964.

Wegglarska, B. 1975. Studies on the morphology of Macrobiotus richtersi Murray, 1911. Mem. Ist. ital. Idrobiol., 32: 445-464. 